\title{
The Use of Methane in Practical Solutions of Environmental Engineering
}

\author{
Aneta Skorek ${ }^{1}$, Renata Włodarczyk ${ }^{2 *}$ \\ 1 Institute of Environmental Engineering, Faculty of Infrastructure and Environment, Częstochowa University \\ of Technology, Brzeźnicka 60A Street, 42-200 Częstochowa, Poland \\ 2 Energy Engineering Department, Faculty of Infrastructure and Environment, Częstochowa University of \\ Technology, Brzeźnicka 60A Street, 42-200 Częstochowa, Poland \\ * Corresponding author's e-mail: rwlodarczyk@is.pcz.pl
}

\begin{abstract}
Methane is the main component of the basic conventional fuels used in modern energetics - natural gas, as well as an essential component of renewable fuel like biogas. As a result of technological processes, methane can be extracted from hydrogen fuel which is dedicated to low-temperature fuel cells, generators or electric current and heat. The article reviews the possibilities of using methane to produce electricity, practical solutions and the problems that inhibit the implementation of fuel cell technology.
\end{abstract}

Keywords: biogas, hydrogen, low-temperature fuel cells, methane

\section{INTRODUCTION}

Electricity demand is increasing continuously. Computerization and electronics become a challenge in virtually every field of life. Different forms of energy are used in the production goods. People have long tried to use energy to meet their individual needs, which grew with the development of civilization [Dennis et al., 2006]. It was estimated that humanity used up 500 billion tones of conventional fuel, over $60 \%$ of which over the past century. According to forecasts for the next 100 years, energy consumption will increase by approximately $250 \div 300 \%$ [Bajdor et al., 2011].

The increasing demand for electricity and large production of fossil fuels results in an ever greater loss of natural resources. In addition, the use of minerals has a negative impact on the environment and has many serious consequences [Dennis et al., 2006]. Most scientists recognize that climate change is largely responsible for the greenhouse effect that is primarily caused by the increase in $\mathrm{CO}_{2}$ concentration [Stańczyk et al., 2007]. Carbon dioxide is becoming an interna- tional concern and a number of research projects [Tarkowski, 2005]. However, greenhouse gases also include nitrous oxide, chlorofluorocarbons, halon, industrial gases, ozone, and methane [Hamelinck at al., 2002]. According to the International Energy Agency, the latter is the second most important greenhouse gas, as shown in Figure 1 [IEA, 2017]

The emission of methane on Earth comes from the natural and anthropogenic sources. The natural sources include volcanic activity and biological activity of flora and fauna [Berndes et al., 2002]. In turn, the anthropogenic sources, such as those generated by human activity, include the production of cement and other carbonaceous substances, the burning of fossil fuels, the sector of waste management, agriculture and land use, especially deforestation.

One of the ideas of reducing methane from the atmosphere is to employ its properties for energy purposes. The aim of this article is to present of the possibilities of using methane for direct and indirect production of electricity, specifying unconventional non-renewable energy sources, i.e. fuel cells. 




$\square$ Carbon dioxide $\square$ Fluorinated gases $\square$ Methane $\square$ Nitrous oxide

Figure 1. The percentage of greenhouse gas emissions in 2014, based on [US EPA, 2017]

\section{PHYSICAL AND CHEMICAL PROPERTIES OF METHANE}

The simplest organic compounds are saturated hydrocarbons, called, in accordance with systematic nomenclature, alkanes. These compounds are composed exclusively of carbon and hydrogen, and the carbon atoms in their molecules are joined together by individual bonds. The simplest representative of the alkanes is the methane $-\mathrm{CH}_{4}$.

Physically, methane is a colorless and odorless gas, lighter than air [Ogden et al. 1999]. Methane is very poorly soluble in water (23 $\mathrm{mg} \mathrm{l}^{-1}$ at $20^{\circ} \mathrm{C}$ ) and acetone, but is well soluble in alcohols (methanol, ethanol), ether and aromatic hydrocarbons (benzene and toluene) [Antonopoulou et al., 2008].

Methane is a combustible gas, the burning of air with sufficient completely:

$$
\mathrm{CH}_{4}+2 \mathrm{O}_{2} \rightarrow \mathrm{CO}_{2}+2 \mathrm{H}_{2} \mathrm{O}
$$

The reaction products (1) are carbon dioxide and water vapor. By measuring the volume of methane used and the resulting combustion products (under the same temperature and pressure conditions), one can see that they are in a 1:1:2 ratio. With limited air access, methane combustion products are: carbon monoxide (water vapor) and water vapor (reaction 2 ):

$$
2 \mathrm{CH}_{4}+3 \mathrm{O}_{2} \rightarrow 2 \mathrm{CO}+2 \mathrm{H}_{2} \mathrm{O}
$$

or soot and water vapor (reaction 3):

$$
\mathrm{CH}_{4}+\mathrm{O}_{2} \rightarrow \mathrm{C}+2 \mathrm{H}_{2} \mathrm{O}
$$

Methane mixtures with air are highly explosive, which is the cause of dangerous explosions in hard coal mines [Ogden et al., 1999]. The characteristic parameters and their values for methane are shown in Table 1.

Please note the given methane values in Table 1, compared with the calorific value of fuels commonly used in power industry (Figure 2). The calorific value of methane is higher: 1.1 times than that of petrol, 1.7 times than that of coal, 2.4 times from lignite and 2.6 times from biomass (pine wood).

The calorific value of methane is in turn similar to natural gas. This is due to the fact that methane is a basic component of natural gas. Natural gas contains more than $90 \%$ methane [Wołoszyn et al., 2003]. The second most common fuel is methane, which is biogas [Hamelinck et al., 2006]. According to the Polish Act on renewable energy sources, biogas is defined as "gas obtained from biomass, in particular from the processing of animal or vegetable waste, sewage treatment plants and landfills" [The Act, 2015]. It is precisely from the composition of the substrates, the chemical composition of biogas is largely dependent (Table 2). According to [Kwaśny et al., 2012], the most methane in biogas is obtained from agro-food industry (68\%) 
Table 1. Physicochemical properties of methane [Ogden et al., 1999; Tor et al., 2001]

\begin{tabular}{|l|c|c|}
\hline \multicolumn{1}{|c|}{ Parameter } & Unit & Value \\
\hline Normal density & $\mathrm{kg} \cdot \mathrm{m}^{-3}$ & 0.72 \\
\hline Boiling point & ${ }^{\circ} \mathrm{C}$ & -161.69 \\
\hline Melting point & ${ }^{\circ} \mathrm{C}$ & -184.00 \\
\hline Critical temperature & ${ }^{\circ} \mathrm{C}$ & -82.10 \\
\hline Flash point of methane-air mixture & ${ }^{\circ} \mathrm{C}$ & $650-1100$ \\
\hline Critical pressure & $\mathrm{MPa}$ & 4.64 \\
\hline Critical density & $\mathrm{kg} \cdot \mathrm{m}^{-3}$ & 162.00 \\
\hline Molar mass & $\mathrm{kg} \cdot \mathrm{kmol}^{-1}$ & 16.04 \\
\hline Constant gas & $\mathrm{J}\left(\mathrm{kg}^{-1} \cdot \mathrm{K}^{-1}\right)$ & 518.37 \\
\hline Specific heat capacity & $\mathrm{kJ}\left(\mathrm{kg}^{-1} \cdot \mathrm{K}^{-1}\right)$ & 2.18 \\
\hline \multirow{2}{*}{ Calorific value } & $\mathrm{MJ} \cdot \mathrm{m}_{\mathrm{n}}^{-3}$ & 35.89 \\
\hline \multirow{2}{*}{ Heat of combustion } & $\mathrm{MJ} \cdot \mathrm{kg}^{-1}$ & 50.50 \\
\hline Stoichiometric concentrations & $\mathrm{MJ} \cdot \mathrm{m}_{\mathrm{n}}^{-3}$ & 39.83 \\
\hline Lower limit of explosion & $\mathrm{MJ} \cdot \mathrm{kg}^{-1}$ & 55.53 \\
\hline Upper limit of explosion & $\%(\mathrm{volumetric})$ & 9.48 \\
\hline Minimum ignition energy in air & $\%(\mathrm{volumetric})$ & 5.00 \\
\cline { 2 - 3 } & $\%(\mathrm{volumetric})$ & 15.00 \\
\cline { 2 - 3 } & $\mathrm{mJ}$ & 0.25 \\
\hline
\end{tabular}



Figure 2. Comparison of calorific value of methane with other fuel values of fuels, based on [Dudek et al., 2010; Skorek et al., 2016; Tor et al., 2001]

and the least from households (50-60\%). In the item [The Act, 2015], however, one can find quite another range of methane content from municipal waste, amounting to $25-65 \%$. This interval includes both natural gas outflow from the bed $(60-65 \%)$, suction and good sealing of waste heap (45-50\%) and suction from badly sealed heap of waste $(25-45 \%)$.

The use of natural gas and biogas for the production of electricity can be considered as the direct use of methane for energy purposes. For example, natural gas is used as fuel in gas power plants. Unlike the steam power plant, steam boilers are ignored in the gas power plants, so the efficiency of converting chemical energy into electricity is higher [Hamelinck et al., 2006]. In addition, gas power plants emit $45 \%$ less carbon dioxide than coal-fired power stations [Kwinta et al., 2010].

The typical examples of biogas use are the production of electricity production of heat in adapted gas boilers or simultaneous production of electricity and heat in associated units [Dudek et al., 2010].

There are significant differences between the natural gas and biogas as shown in Table 3 . If injection of biogas into a regional natural gas network or compression in an engine used by mo- 
Table 2. Comparison of chemical composition of biogas produced from different substrates [Kwaśny et al., 2012]

\begin{tabular}{|c|c|c|c|c|c|}
\hline Component & Value & $\begin{array}{l}\text { Waste from agro- } \\
\text { food industry }\end{array}$ & Agricultural waste & $\begin{array}{l}\text { Waste from } \\
\text { households }\end{array}$ & $\begin{array}{c}\text { Sludge from } \\
\text { sewage treatment } \\
\text { plant }\end{array}$ \\
\hline $\mathrm{CH}_{4}$ & \multirow{4}{*}{$\begin{array}{c}\% \\
\text { (volumetric) }\end{array}$} & 68 & $60-75$ & $50-60$ & $60-75$ \\
\hline $\mathrm{CO}_{2}$ & & 26 & $19-33$ & $34-38$ & $19-33$ \\
\hline $\mathrm{N}_{2}$ & & - & $0-1$ & $0-5$ & $0-1$ \\
\hline $\mathrm{O}_{2}$ & & - & $<0.5$ & $0-1$ & $<0.5$ \\
\hline $\mathrm{H}_{2} \mathrm{O}$ & $\begin{array}{c}\% \\
\text { (volumetric) } \\
(313.15 \mathrm{~K})\end{array}$ & 6 & 6 & 6 & 6 \\
\hline $\mathrm{H}_{2} \mathrm{~S}$ & \multirow{4}{*}{$\mathrm{mg} \cdot \mathrm{m}^{-3}$} & 100 & $3000-10000$ & $100-900$ & $1000-4000$ \\
\hline $\mathrm{NH}_{3}$ & & 400 & $50-100$ & - & - \\
\hline $\begin{array}{l}\text { Fluorine or halogen } \\
\text { organic compounds }\end{array}$ & & - & - & $100-800$ & - \\
\hline Aromatic compounds & & - & - & $0-200$ & - \\
\hline
\end{tabular}

tor vehicles is planned, it should be overflowed. It is necessary to eliminate hydrogen sulphide and water vapor (sulfuric acid causes corrosion of individual components of the plant) and the separation of carbon dioxide into methane [Borek et al., 2015].

\section{UTILIZATION OF METHANE IN FUEL CELLS}

Another possible indirect use of methane for electricity generation is fuel cells, especially low temperature cells. Low temperature cells are systems that work continuously for a long time, in the temperature range $80-100^{\circ} \mathrm{C}$ [Murphy at al., 2005; Włodarczyk, 2011]. The most common types of low temperature cells are Proton Exchange Membrane Fuel Cells (PEMFC).

A single PEMFC cell (Figure 3) consists of two electrodes: negative (anode) and positive (cathode). The electrodes are separated by electrolyte, which in the solid form is called a mem- brane. Electrolytes and electrodes are placed between the covers (graphite plates) containing the ducts to feed the fuel (hydrogen) and the oxidant (oxygen supplied in pure form or from the air) and drainage or water vents [Włodarczyk et al., 2009].

In the fuel cell of the PEMFC type, an oxygen reaction with hydrogen occurs:

$$
2 \mathrm{H}_{2(\mathrm{~g})}+\mathrm{O}_{2(\mathrm{~g})} \rightarrow 2 \mathrm{H}_{2} \mathrm{O}_{(\mathrm{c}}
$$

The reaction (4) takes place without burning, and therefore is safe. Hydrogen flows around the anode, and the oxygen around the cathode. The surface of the anode is usually covered with platinum, a catalyst characterized by high conductivity. The catalyst pulls electrons from each hydrogen atom, causing the ionization. As a result of the neutral hydrogen atom, a positively charged ion and free electrons are formed. Electrons and hydrogen ions travel to the cathode: ions through the electrolyte, electrons through the periphery of the cell, producing a constant electric current. The only by-products of the re-

Table 3. Comparison of chemical composition of natural gas with biogas [Borek et al., 2015]

\begin{tabular}{|c|c|c|c|c|}
\hline \multirow{2}{*}{ Component } & \multicolumn{2}{|c|}{ Biogas } & \multicolumn{2}{|c|}{ Natural gas } \\
\hline & medium & range & crude & commercial \\
\hline $\mathrm{CH}_{4}$ & $60 \%$ & $50-75 \%$ & $75-95 \%$ & $90-98 \%$ \\
\hline $\mathrm{CO}_{2}$ & $39 \%$ & $25-45 \%$ & $2-20 \%$ & $1-3 \%$ \\
\hline $\mathrm{N}_{2}$ & $0.4 \%$ & $0-3 \%$ & $0-2 \%$ & $<1 \%$ \\
\hline $\mathrm{O}_{2}$ & $0.1 \%$ & $0-1 \%$ & - & - \\
\hline $\mathrm{H}_{2} \mathrm{O}$ & saturated & saturated & saturated & < 10 ppm \\
\hline $\mathrm{H}_{2} \mathrm{~S}$ & $0.1 \%$ & $0-1 \%$ & $0-2 \%$ & $<5 \mathrm{ppm}$ \\
\hline $\mathrm{NH}_{3}$ & $0.05 \%$ & $0-0.5 \%$ & - & - \\
\hline Higher hydroxides & - & - & $1-5 \%$ & $1-5 \%$ \\
\hline
\end{tabular}


1) electrolyte/membrane

2) catalyst layer

3) gas diffusion layer

4) hydrogen flow field

5) oxidant flow field

6) interconnect

7) fuel electrode (anode)

8) air electrode (cathode)

9) Membrane Electrode

Assembly

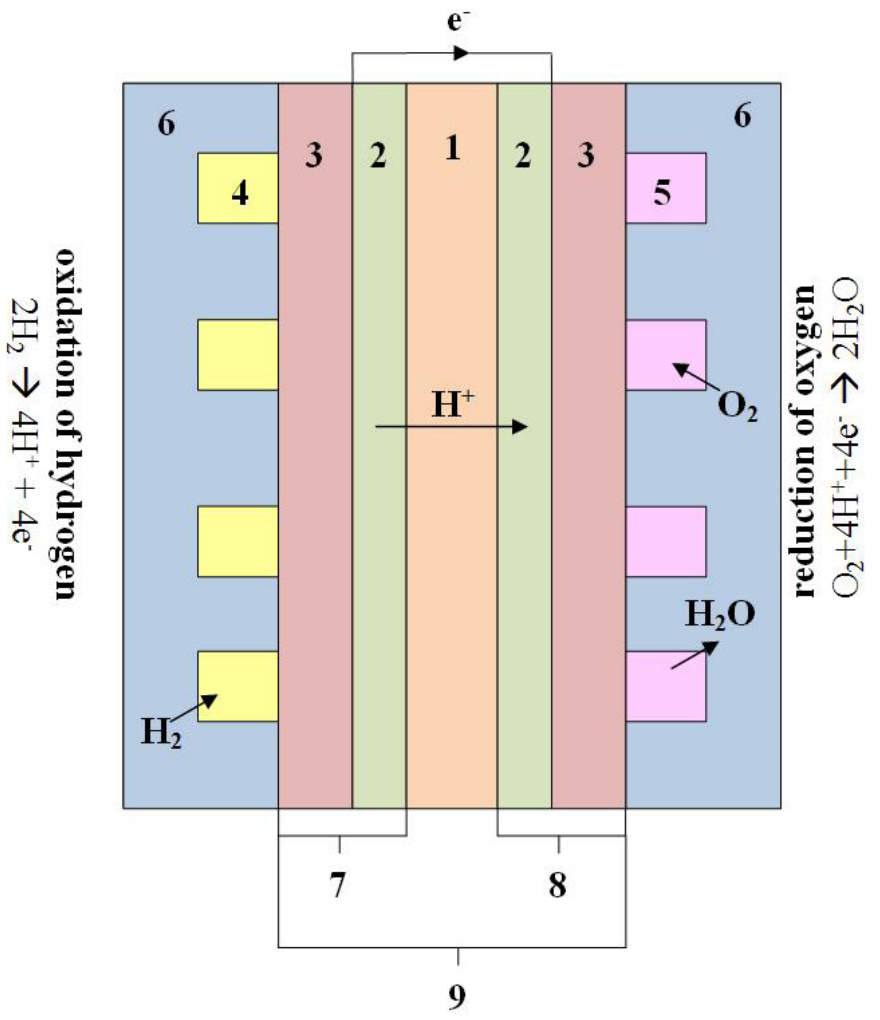

Figure 3. PEMFC fuel cell construction scheme, own elaboration on the basic of [Włodarczyk et al., 2009]

action include water and heat. The formed water is distilled from the electrolyte and can be used for other purposes [Włodarczyk et al., 2009; Włodarczyk et al., 2016].

At first it was thought that fuel cells would only be of limited use, mainly in some niche projects such as spaceflight (aerospace) or the armaments industry (e.g. submarines). Currently, a large number of tested applications proved the great versatility of this technology [Chaczykowski, 2006]. PEMFC cells can be used as power sources for portable power plants of several milliwatts and power plants of several megawatts [Hermann et al., 2005]. The list of possible solutions is extremely wide, ranging from communications applications (individual transport and collection), to the supply of portable devices (e.g. laptops, cell phones), emergency power supply systems, electricity and heat sources in home and industrial applications, power plants [Włodarczyk, 2011].

The technological barrier to the use of PEMFC cells is the technological process of obtaining hydrogen on a large scale using relatively cheap technology [Skorek et al., 2016]. Hydrogen is found in the form of chemicals, i.e. water, hydrides, hydrocarbons [Lipman, 2011]. Hydrogen can be obtained in a thermal or electrochemical way from natural fuels and water. The research on the biological methods is also being carried out in the world [Santoro et al., 2017].

The most popular hydrogen-producing process is the reform of natural gas, classified as thermal methods [Skorek et al., 2016]. The basic processes of thermochemical processing of natural gas are reforming: steam reforming (SR), direct partial oxidation (DPO), partial oxidation (POX) and autothermal reforming (ATR). A well-known dry methane reforming (DMR) is employed for some chemical syntheses [Warowny, 2008]. According to [Demusiak, 2012] the optimum solution for PEMFC cells is the use of steam reforming.

Steam reforming is the process of passing a mixture of natural gas and water vapor through the catalyst bed. In the first step of the process, the catalytic reaction (5) of the methane splitting at 600-800 ${ }^{\circ} \mathrm{C}$ occurs in the endothermic reformer:

$$
\mathrm{CH}_{4}+\mathrm{H}_{2} \mathrm{O} \rightarrow 3 \mathrm{H}_{2}+\mathrm{CO}
$$

The volume of hydrogen in the gas that is the product of the reformer's reaction is about $8-12 \%$. In the next step, there is a reaction (6) reduction of carbon monoxide by steam with a temperature of $200-350{ }^{\circ} \mathrm{C}$ : 


$$
\mathrm{CO}+\mathrm{H}_{2} \mathrm{O} \rightarrow \mathrm{H}_{2}+\mathrm{CO}_{2}
$$

After washing the $\mathrm{CO}_{2}$, hydrogen is obtained at a purity level greater than $99 \%$. However, the degree of purification of carbon monoxide required by the PEMFC type cell is not achieved here (this level should not exceed 15 ppm). In order to be able to use hydrogen in PEMFC cells, partial oxidation of carbon monoxide remaining with a small amount of air at $100^{\circ} \mathrm{C}$ (reaction 7) is used:

$$
2 \mathrm{CO}+\mathrm{O}_{2} \rightarrow 2 \mathrm{CO}_{2}
$$

The steam reforming described by reaction (5) and (6) is a total endothermic reaction requiring $165 \mathrm{~kJ} / \mathrm{mol}$ of heat. As a result, the heat required for the steam reforming process decreases the amount of heating energy obtained from the PEMFC type cell [Chaczykowski 2006].

Practically, [Demusiak 2012] points out that the optimum solution for PEMFC cells is the use of the steam reforming method (using a nickel catalyst in the first stage) in combination with the following two conversion steps for carbon monoxide: high temperature (with chromium-chromium catalyst) and low temperature (with copper catalyst or copper-zinc catalyst). The final stage of the process should be the catalytic oxidation of carbon monoxide on catalysts (platinum or palladium) with a small addition of air. The initial stage of the entire process should be a very good desulphurisation of natural gas, using appropriately selected low temperature sorbents, depending on the composition of the gas to be treated (including the content of the sulfur impurities, the amount of gas stream and the necessary degree of gas purification).

An interesting technological solution may be the use in the reforming process of methane obtained from methane fermentation from municipal waste (renewable fuel). Even more so, considering that the growing landfills become a serious problem. Annually, about 130 million tons of waste is produced, and the oxidizing methane is adversely affecting the environment [Kwinta, 2010]. In addition, municipal waste is a substrate commonly available at landfills and does not contribute to the reduction of natural sources of energy. Municipal waste, as a free energy source, can lead to the lowering of production costs and the use of fuel cells.

\section{CONCLUSIONS}

As a result of the literature review, the following conclusions were drawn:

1. Because of its physicochemical properties, methane can respond to the increasing demand for electricity in the world.

2. The use of methane for energy purposes leads to its reduction in the atmosphere, which is a measurable benefit in terms of counteracting climate change.

3. An interesting technological proposal is the use of methane derived from waste to produce hydrogen for low temperature cells.

4. The production of hydrogen produced from the waste fermentation (methane) product can lead to the reclassification of low temperature cells to unconventional renewable generators of electricity and heat.

5 . With the use of renewable fuel (waste), serial fuel cell production can be introduced.

\section{REFERENCES}

1. Antonopoulou G., Gavala H.N., Skiadas I.V., Angelopoulus K., Lyberatos G. 2008. Biofuels generation from sweet sorghum: Fermentative hydrogen production and anaerobic digestion of the remaining biomass. Bioresource Technology, 99, 110-119.

2. Bajdor K., Biernat K. 2011. Biofuels as alternative energy carriers in internal combustion engines, classification and development perspectives (in Polish). Archiwum Motoryzacji, 1, 5-19.

3. Berndes G., Hoogwijk M., Broek R. 2003. The contribution of biomass in the future global energy supply: a review of 17 studies. Biomass and Bioenergy, 25, 1-28.

4. Borek K., Barwicki J., Mazur K., Majchrzak M., Wardal W.J. 2015. Evaluation of the impact of digestate formed during biogas production on the content of heavy metals in soil. Agricultural Engineering, 2(154), 15-23.

5. Chaczykowski M. 2006. Stationary fuel cells powered by natural gas (in Polish). Nowoczesne Gazownictwo, 11, 5-12.

6. Demusiak G. 2012. Obtaining hydrogen fuel by natural gas reforming for low-power fuel cells (in Polish).Nafta-Gaz, 10, 671-672.

7. Dennis M.N., Leung Y.C., Leung M.K.H., Sumathy K. 2006. An overview of hydrogen production from biomass. Fuel Proc Technology, 87, 461-472.

8. Dudek J., Zalewska-Bartosz J., 2010. Acquisition and use of biogas for energy purposes (in Polish). 
Problemy Ekologii, 14, 13-16.

9. Hamelinck C.N., Faaij A.P.C., 2002. Future prospects for production of methanol and hydrogen from biomass. Journal of Power Sources, 111, 1-22.

10. Hamelinck C.N., Faaij A.P.C., 2006. Outlook for advanced biofuels. Energy Policy, 34, 3268-3283.

11. Hermann A., Chaudhuri T., Spagnol T., 2005. Bipolar plates for PEM fuel cells: A review. Int. J. Hydrogen Energy, 30, 1297-1302.

12. International Energy Agency (IEA), http://www. iea.org/publications/freepublications/publication/ methane_brochure.pdf [read: 03.02.2017].

13. Kwaśny J., Banach M., Kowalski Z., 2012. Overview of biogas production technologies of various source (in Polish). Technical Transactions. Chemistry, 2(17), 83-102.

14. Kwinta W. 2010. The role of methane in energy will increase (in Polish); Polska Energia - Polish Energy; 1:

15. http://www.cire.pl/pliki/2/wzrosnrolametanu.pdf [read: 08.02.2017].

16. Lipman T. 2011. An overview of hydrogen production and storage systems with renewable hydrogen case studies. A clean energy states alliance report. 5-32. [read: 09.02.2017].

17. Murphy J.D., McCarthy K. 2005. Ethanol production form energy crops and wastes for use as a transport fuel in Ireland. Applied Energy, 82, 148-166.

18. Ogden J.M., Steinbugler M.M., Kreutz T.G., 1999. A comparison of hydrogen, methanol and gasoline as fuels for fuel cell vehicles:implications for vehicle design and infrastructure development. J Power Sources, 79, 143-168.

19. Santoro C., Arbizzani C., Erable B., 2017. Microbial fuel cells: From fundamentals to applications. A review. Journal of Power Sources, 356, 225-244.

20. Skorek A., Dreksler M., Włodarczyk R., 2016. Hydrogen as contemporary source of energy, [In:] Limiting $\mathrm{CO}_{2}$ emissions - combating climate change (in Polish), I. Majchrzak-Kucęba, A. Ściubidło (Eds.), CUT Publishing House, Częstochowa, 98-115.
21. Stańczyk K., Bieniecki M. 2007. CO2 emissions reduction and its effect on efficiency and cost of energy manufacture from coal (in Polish). Górnictwo i Geoinżynieria - Mining and Geoengineering, 31(2), 575-586.

22. Tarkowski R. 2005. Geological CO2 sequestration (in Polish), Publisher of the Institute for Mineral Resources and Energy, Polish Academy of Sciences, Kraków.

23. The Act of 20 February 2015 the renewable energy sources (in Polish) (Dz.U. z 2015 r. poz. 478).

24. Tor A., Gatnar K, 2001. Drainage and economical utilization of methane-gas from coal seams in the mining field Jastrzębie Coal Company in cogeneration power system (in Polish). Proceedings of International Scientific Conference "Geothermal Energy in Underground Mines" Ustroń.

25. United States Environmental Protection Agency (US EPA), 2017. http://www.epa.gov/ghgemissions/ overview-greenhouse-gases, [read: 06.02.2017].

26. Warowny W., 2008. Fundamental technologies of thermal acquisition (in Polish). Gaz, Woda i Technika Sanitarna, 3, 8-14.

27. Włodarczyk M., Łopaciuch P., Włodarczyk R., 2016. Low-temperature hydrogen fuel cells - construction, principle of operation, development prospects (in Polish): Limiting $\mathrm{CO}_{2}$ emissions - combating climate change, I. MajchrzakKucęba, A. Ściubidło (ed.), CUT Publishing House, Częstochowa, 117-128.

28. Włodarczyk R., Dudek A., Kobyłecki R., Bis Z., 2009. Characteristics of the possibilities and the use of fuel cells (in Polish): Polish Environmental Engineering five years after joining the European Union Vol. 2, J. Ozonek, A. Pawłowski (Eds.), Polish Academy of Sciences Committee for Environmental Engineering, Lublin.

29. Włodarczyk R. 2011. Study of performance of materials used for the fuel cell interconnectors PEMFC (in Polish), CUT Publishing House, Częstochowa.

30. Wołoszyn R. 2003. Natural gas as a fuel for motor vehicles (in Polish). Eksploatacja i Niezawodność - Maintenance and Reliability, 3, 19-22. 